\title{
International Oil Companies Sustainability after Oil Price decline
}

\author{
Adrian D. TANTAU \\ The Bucharest University of Economic Studies, Bucharest, Romania \\ adrian.tantau@fabiz.ase.ro \\ Mohammadreza KHORSHIDI \\ The Bucharest University of Economic Studies, Bucharest, Romania \\ m.khorshidi@live.com \\ Ali Asghar Sadeghi MOJARAD \\ The Bucharest University of Economic Studies, Bucharest, Romania \\ sadeghimojarad@hotmail.com
}

\begin{abstract}
International Oil Companies (IOC's) had been playing a major role in oil industry at the beginning of $20^{\text {th }}$ century. They had many volatility during last century and faced with many obstacles which forced them to change their business models and improve their outcome to satisfy their shareholders. One of the most important challenges was oil nationalization in oil producer countries which were happened by establishment of NOCs. Later green energy issue which came from CO2 emission problem happened and recently, oil and gas price diminish challenges, involve all IOCs with the most important challenge in last century after all. Among all those events, one of the most important key values which have been observed by IPIECA, API and IOGP associations every year is Sustainability. The objectives of the research are study all issues and indicators of sustainability in IOCs. Each indicator has faced with different strategy via IOCs in different market situation. The importance of this key value cause that it is observed by some important association like IPIECA, API and IOGP each year. As the scarcity of related references for business model in oil and gas industry, literature review of some resources and annual sustainability report followed by a questionnaire as a survey are also selected methods for recent major challenges to achieve required result.
\end{abstract}

Keywords: oil price, business model, international oil companies, key value, key activity, sustainability.

\section{Introduction}

Based on The U.S. Energy Information Administration (EIA) in its article from January, $6^{\text {th }}$ 2015, crude oil prices fell sharply in the last quarter of 2014 as demand was less than production. The peak price of Brent was $\$ 112 / \mathrm{bbl}$ and price of West Texas Intermediate was $\$ 105 / \mathrm{bbl}$ in June, then they fell sharply to $\$ 62 / \mathrm{bbl}$ and $\$ 59 / \mathrm{bbl}$ in December, respectively and this decline continued to around $\$ 30 / \mathrm{bbl}$. 


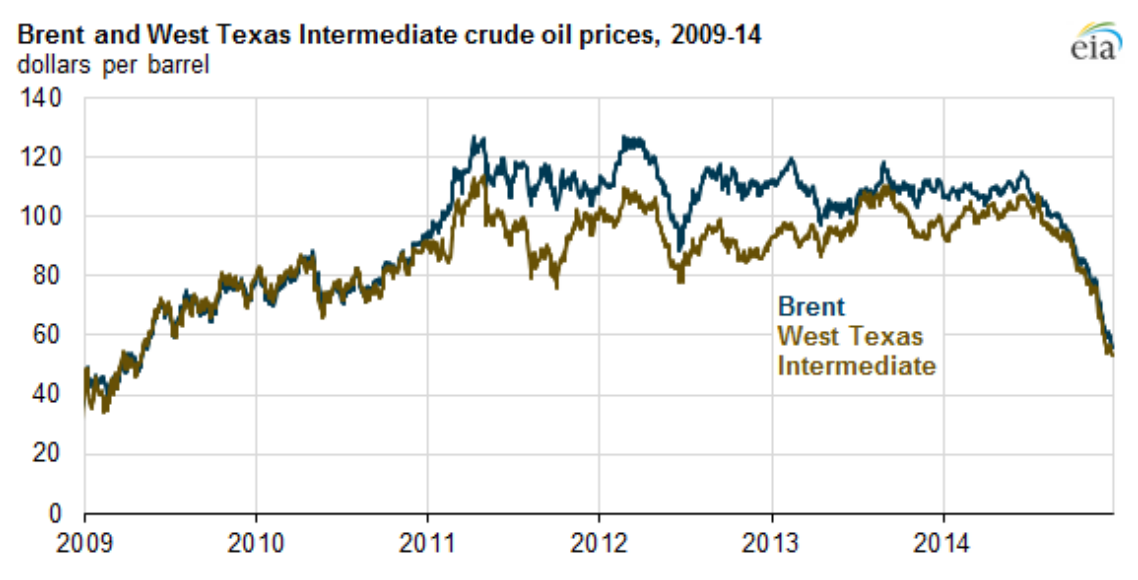

Figure 1. Crude oil price 2009-2014

Source: The U.S. Energy Information Administration(EIA), January $6^{\text {th }} 2015$.

Therefore, International Oil Companies(IOCs) had been challenging with market slow down and many of those companies had to alter some of their crucial policies or attitudes. Business model of IOCs was impacted and study on its important key values to designing a new, constructive business model with low market situation and focused on sustainability is mandatory (see figure 2).

A first international accepted definition of sustainability was promoted in 1987 by the World Commission on Environment and development as "'the development that meets the needs of the present generation without compromising the ability of future generations to meet their own needs" (Brundtland Report, 1987).

In our research sustainability has three main issues which are Environmental, Health and safety, Social and economic (see figure 2).

Each issue has some indicators that this article tries to investigate about them and clarify situation of sustainability while the market is low and oil and gas business struggling with market slow down.

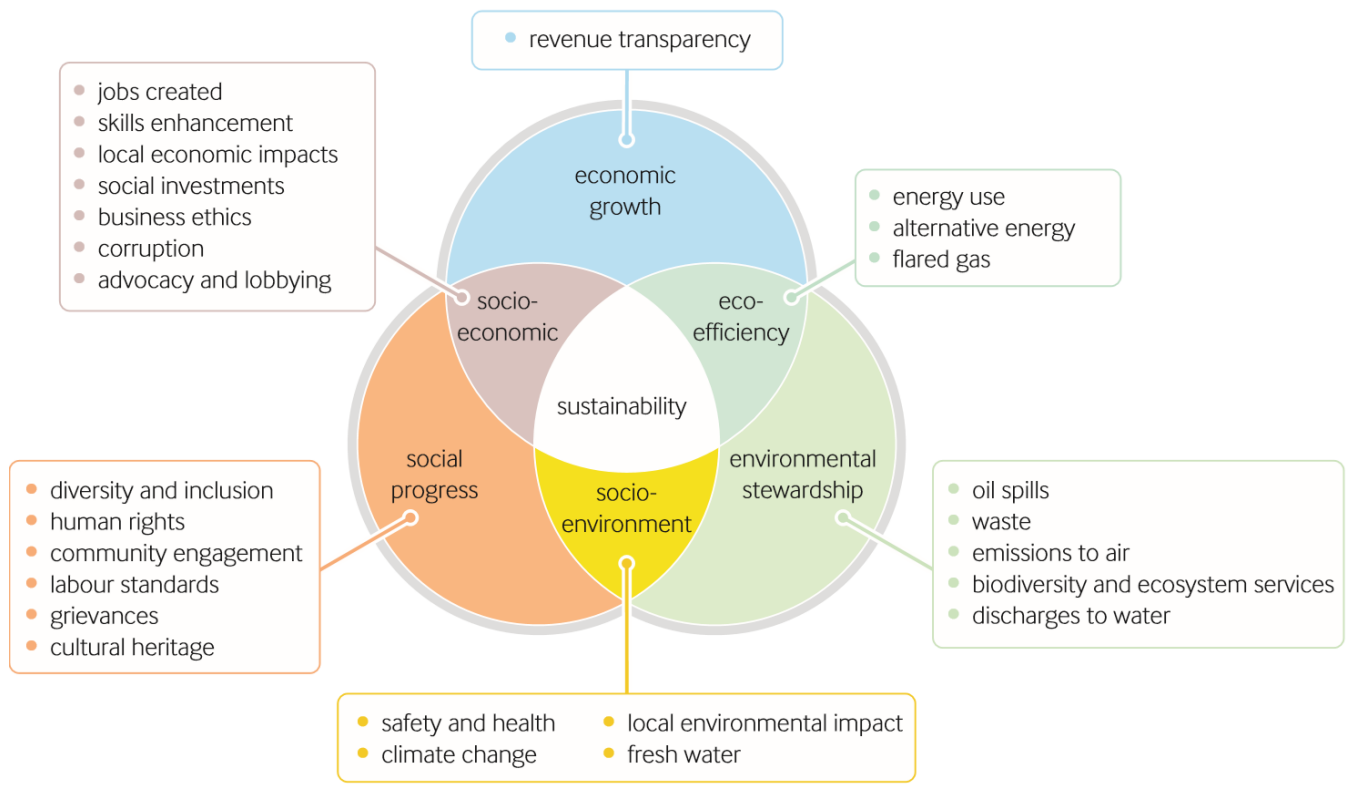

Figure 2. Sustainability issues and indicators

Source: IPIECA (2015) Third edition of sustainability reporting guidance for the oil and gas industry, http://www.ipieca.org, accessed, 16 December 2016. 
Most researches were about financial issues of market slow down after 2014, while domestic society issues, business ethics, labor standards, corruption, and skill enhancement and environmental issues were in minority issues which researchers investigate about them less than others. Mentioned issues are among issues which easily might be omitted from oil and gas companies' business model because of market slow down and the loss or less profit margin caused by decreased price.

Issues like corruption, business ethics, labor standards and each issue related to domestic society are so crucial to pretend from omitting though companies try avoid some expenses which does not have any direct effect on their activities like exploration and production.

According to the subject, following hypotheses are the point of view of this article that supports by a questionnaire and collect experts' idea related to the main topic and finally in conclusion part is concluded.

- During last market, crucial challenge which was market slowdown, social and economic aspect of sustainability emphasized more than other aspects.

- Environmental aspects of sustainability are more crucial in oil and gas upstream sector after oil price declination than other aspects of sustainability.

In the oil\&gas sector Arscot (2004) explain the concept of sustainability of human existence as a proper balance between the social, economic and environmental capital in a changing world.

Before talking about sustainability as a key value of business model and competitiveness (Dima et al., 2016), it's necessary to talk about value chain of oil and gas industry. Value proposition of each business model has a direct relation to the company business activities. Business activities in oil and gas industry are in a wide range from extraction to natural resources transformation to other types of energy or products from oil fields to customer in all around the world (figure3).
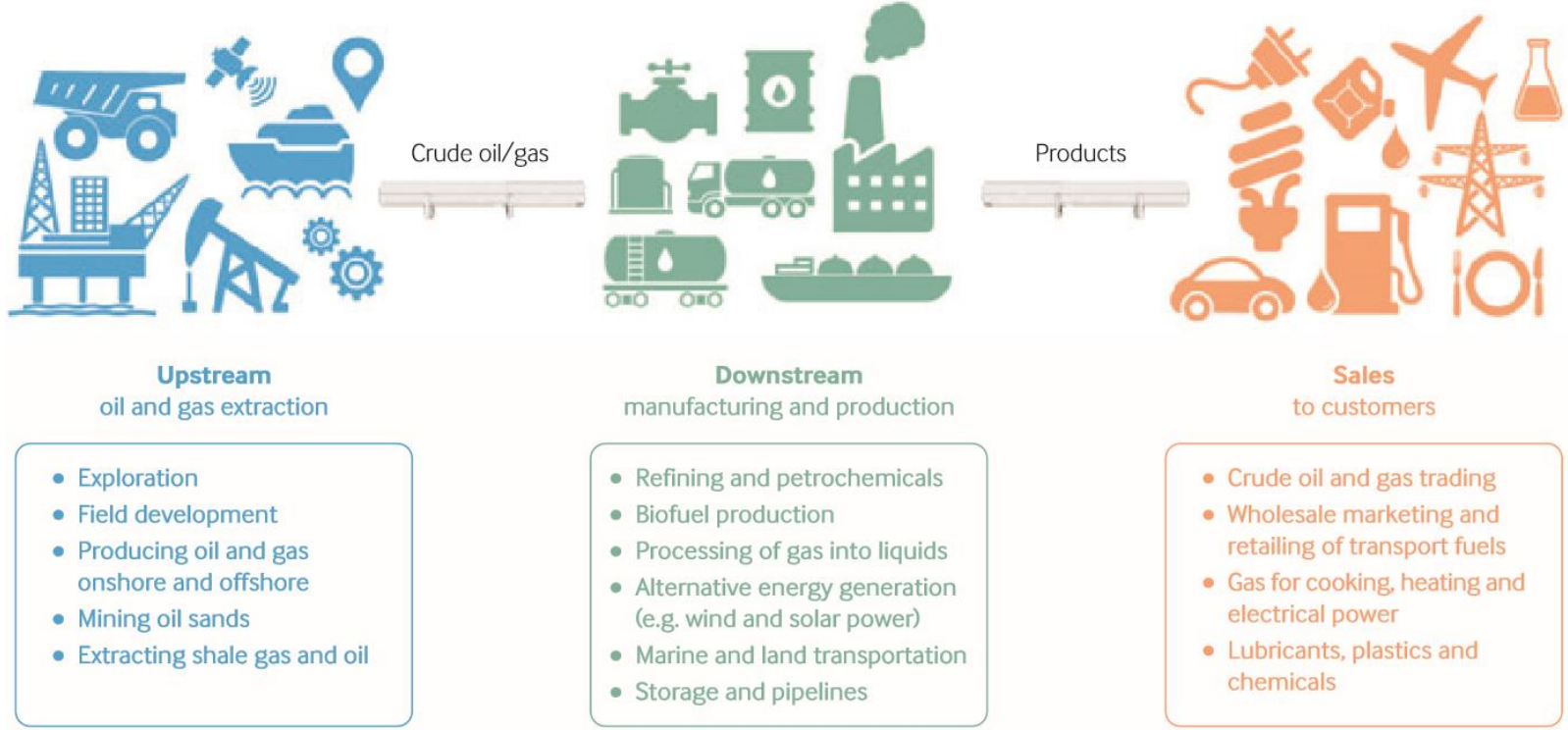

Figure 3. Oil and gas industry sectors

Source: IPIECA (2015) Third edition of sustainability reporting guidance for the oil and gas industry, http://www.ipieca.org, accessed, 16 December 2016. 
In order to be efficient the indicators have to be credible and legitimate Bauler (2012). The legitimacy of the indicators refers on their acceptability and credibility and is based on the validity, consistency and quality of data (Heinket et al., 2015). The indicators are more credible if they contain relevant information and also a comprehensive explanation that is accessible (Pupphachai \& Zuidema, 2016).

Before analyzing the main issues and indicators for sustainability in the oil \& gas sector we reviewed the factors that influenced the supply chain sustainability. Studies demonstrated that the stakeholders are the main factors that influence the supply chain sustainability goals. This influence has different issues in the upstream chain where the focused is oriented on ownership and access to reserves compared to the downstream where the higher risk is taken by consumers and by suppliers. (Ahmad et all, 2016). As a result there is a need to identify the relevant stakeholders in order to define a proper sustainable supply chain strategy. Baumgartner (2014) consider that for defining a corporate sustainable strategy the sustainability issues give the basic information.

Environmental issue and indicators represent a first main dimension of sustainability. These are crucial, as operations have direct relation with environment.

The first group of sustainability indicators is related to climate change and energy are GHG emissions, energy use, renewable energy sources and flared gas. A second group of indicators for sustainability is related to biodiversity and ecosystem services. Water represent the third main group of indicators for sustainability. Other local specific indicators for environment impact include, air emissions, Spills to the environment, waste and decommissioning.

The social objective represents a second main dimension of sustainability. This dimension is represented in oil \& gas sector by health and safety indicators which are focused on workforce protection, workforce health and occupational injury and illness incidents, product observation and process safety.

There are studies that consider that there is a lack of harmonization for regulations in the oil\&gas sector and the health, environmental and safety standards are on a low level. So far are missing enforcements mechanisms that could provide that the companies that are involved in the offshore oil and gas exploration and development have implemented sustainability standards (Silvestre et. all, 2016).

Therefore, those data should update constantly and third party organization must consider to assess and validate them and authorize them for customer usage. There is one indicator assume for this issue which is product stewardship.

The economic objectives represent a third main dimension of sustainability. The issues for this dimensions includes, local content practices, local hiring practices and performance and local procurement and supplier development.

\section{Methodology}

The required data has achieved from a designated survey which was asked from IOC's online and by direct Email to IOCs' specialists which are working in upstream in various countries. 128 responses were collected. Fundamental data is also selected from annual sustainability reporting with IPIECA, API and IOGP. Framework and structure of questionnaire is based on twenty questions of total twenty-five, five more demographic questions were also added. SPSS was selected to evaluate results (Burns \& Burns, 2008) which were tested by ANOVA. Furthermore, Pearson chi-square test is utilized. In this 
analysis, all derived data from questionnaire will be tested and compare with expected data which statistically expect. The desire level of certainty which shows by $P$ value is the test outcome. This test also shows correlation between cells which have selected for chi-square test.

In chi-square test, we assume that we achieve $r$ levels of variable $A$ and $c$ levels of variable $\mathrm{B}$ then start to generate two hypotheses for each evaluation.

- First hypothesis is that during last market, crucial challenge which was market slowdown, social and economic aspect of sustainability emphasized more than other aspects.

- Second hypothesis is that Environmental aspect of sustainability are more crucial in oil and gas upstream sector after oil price declination than other aspects of sustainability.

For each of above hypothesis, we should examine null hypothesis and alternative hypothesis, following explanation are general explanation of how we test them.

$\mathrm{H}_{0}$ : Variable A and Variable B are independent.

$\mathrm{H}_{\mathrm{a}}$ : Variable A and Variable B are not independent.

Dependency which stated by alternative hypothesis is that both variables has correlation but they have not necessarily a causal relation. Pearson Chi-Square test, achieve relationship between two categorical variables and test whether they have a significant relation or not. Therefore, sample data should use and find degree of freedom while expected frequencies considered and P-value which associated with the test statistic achieved as result.

$$
\begin{aligned}
& \text { (Degree of Freedom) DF }=(r-1) *(c-1) \\
& \text { (Expected Frequency) Er, } c=(n r * n c) / n
\end{aligned}
$$

Where Variable A is sustainability's issues category, variable B is sustainability's issues priority degree, $r$ is the frequency level of Variable $A$ and $c$ is the frequency of Variable B, nr is the total number of sample observations at level $r$ of Variable A, nc is the total number of sample observations at level $c$ of Variable $B$, and $n$ is the total sample size.

(Pearson chi-square test) X2 $=\Sigma[(\mathrm{Or}, \mathrm{c}-\mathrm{Er}, \mathrm{c}) 2 / \mathrm{Er}, \mathrm{c}]$

Where Variable A is sustainability's issues category, variable B is sustainability's issues priority degree $\mathrm{O}_{\mathrm{r}, \mathrm{c}}$ is the observed frequency count at level $r$ of Variable $A$ and level $c$ of Variable $B$, and $E_{r, c}$ is the expected frequency count at level $r$ of Variable $A$ and level $c$ of Variable B.

Probability of observed statistic samples achieved as $P$-value then we could interpret the result and see whether support null hypothesis or not. It could achieve by calculated value which has done by SPSS software and significance level of relation is tested.

Respondents was chosen from oil and gas experts of both NOCs and IOCs to cover all kinds of responses with different point of view. Companies like National Iranian Oil Company, Weatherford, PEDEX, IOOC (Iran Offshore Oil Company), DAFORA drilling company, DAFLOG Well services company were among respondents. 


\section{Research analysis and results}

First, reliability of questions was examined by reliability scale function Cronbach's alpha.

Table 1. Reliability of questions result Reliability Statistics

\begin{tabular}{|r|r|}
\hline Cronbach's Alpha & N of Items \\
\hline .745 & 25 \\
\hline
\end{tabular}

As Table1 shows, the value of Cronbach's Alfa is greater than 0.7 which could consider that questions are moderately reliable.

Sustainability includes environmental, social \& economical and health \& safety as three main issues. In the beginning of the questionnaire tried to find out which issue has been more important for oil and gas companies after oil price experienced a huge decline.

This subject also supported by two more constant questions to receive a precise result which are portrayed in figure3 and figure4. Figure3 is the frequency of each sustainability's aspects and states that social and economical is in the priority of Oil and Gas companies. This issue has $72 \%$ of our population's frequency. Furthermore, figure 4 , states that health \& safety and environmental have lesser importance level than social and economic. In figure4 each sustainability's issue which was asked to be graded in 5 continuous categories from 0 to 100 illustrated. Eventually social \& economical issue earn higher grade in compare with other issues.

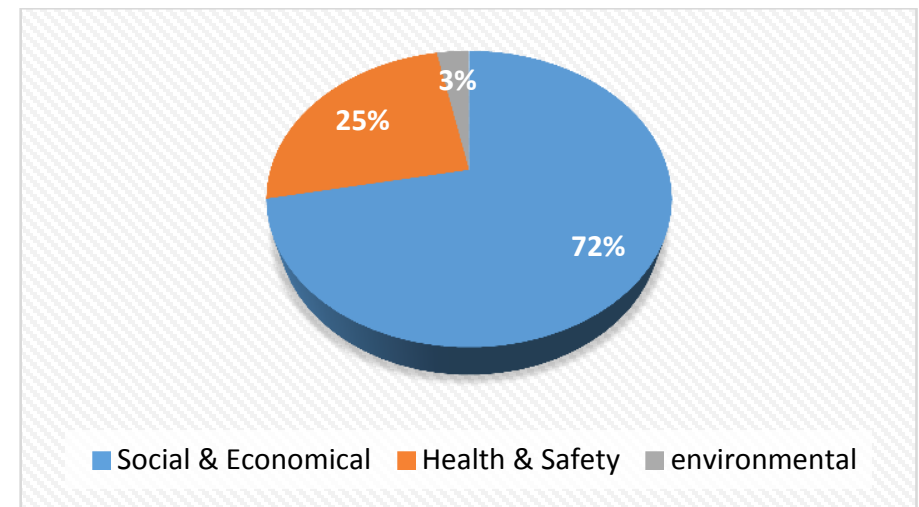

Figure 4. Sustainability aspects frequencies in our sample data

Source: Authors' own research.

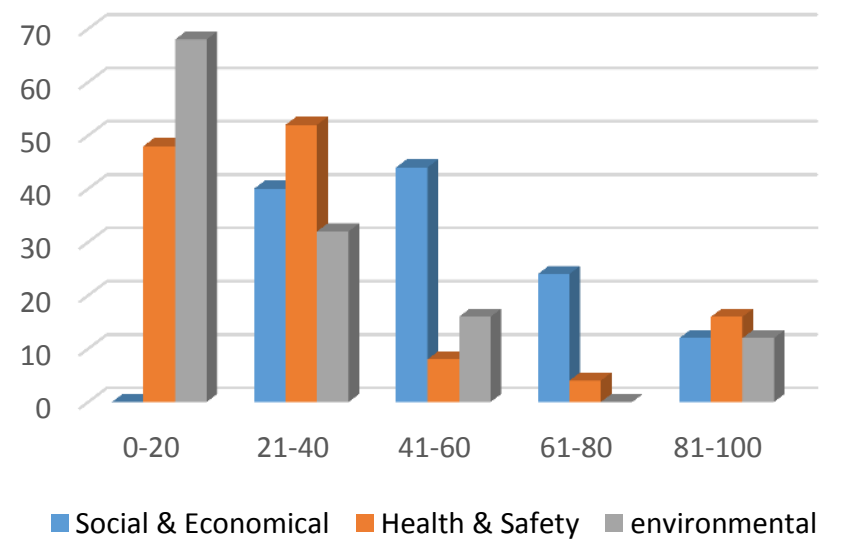

Figure 5. Importance level of each sustainability aspects in our sample data

Source: Authors' own research. 
Chi-square analysis state that regarding above questions, as $P$ value is 0.006 and it is less than 0.05 therefore, null hypothesis reject and we should do a POSTHOC test to identify which groups are significantly dependent. Eventually social \& economical aspect of sustainability which is the highest priority aspect in our sample data is significantly different from other groups.

It supports our first hypothesis which state that during last market, crucial challenge which was market slowdown, social and economic aspects of sustainability emphasized more than other aspects. In the other hand, second hypothesis is rejected, because the Environmental aspect of sustainability does not have significant different in above analysis, so environmental aspect is not more crucial in oil and gas upstream sector after oil price declination than other aspects of sustainability.

Table 2. Chi-Square Tests

\begin{tabular}{|c|c|c|c|}
\hline & Value & $\mathrm{df}$ & $\begin{array}{l}\text { Asymp. Sig. (2- } \\
\text { sided) }\end{array}$ \\
\hline $\begin{array}{l}\text { Pearson Chi-Square } \\
\text { Likelihood Ratio } \\
\text { Linear-by-Linear Association } \\
\mathrm{N} \text { of Valid Cases }\end{array}$ & $\begin{array}{r}21.465^{\mathrm{a}} \\
17.681 \\
.006 \\
128\end{array}$ & $\begin{array}{l}8 \\
8 \\
1\end{array}$ & $\begin{array}{l}.006 \\
.024 \\
.936\end{array}$ \\
\hline
\end{tabular}

a. 0 cells $(0.0 \%)$ have expected count less than 5 . The minimum expected count is .38.

Source: SPSS Test result.

This test result tends us to evaluate questions which were designated for social and economic aspect to clarify more detail about sustainability and find out whether oil and gas companies support sustainability or not in recent years which oil prices decreased. To support this result and see what kind of correlation is exist with types of oil and gas activity field, another chi-square test could be executed. As $P$ value is 0.005 and is less than 0.05 . Null hypothesis reject therefore, sustainability issues and companies' activity sector are significantly dependent. Following data are SPSS output regarding chi-square test which have executed on two sustainability issues category and activity field category.

Table 3. Chi-Square test Chi-Square Tests

\begin{tabular}{|c|c|c|c|}
\hline & Value & $\mathrm{df}$ & $\begin{array}{l}\text { Asymp. Sig. (2- } \\
\text { sided) }\end{array}$ \\
\hline $\begin{array}{l}\text { Pearson Chi-Square } \\
\text { Likelihood Ratio } \\
\text { Linear-by-Linear Association } \\
\mathrm{N} \text { of Valid Cases }\end{array}$ & $\begin{array}{r}18.481^{\mathrm{a}} \\
18.676 \\
4.595 \\
128\end{array}$ & $\begin{array}{l}6 \\
6 \\
1\end{array}$ & $\begin{array}{l}.005 \\
.005 \\
.032\end{array}$ \\
\hline
\end{tabular}

a. 0 cells $(00.0 \%)$ have expected count less than 5 . The minimum expected count is .13 .

Source: SPSS Test result.

Such an obvious relation is between oil and gas industry and social and economic issue which is one of most important challenge of this industry as social and economic could have direct effect on the industry and vice versa.

According to oil and gas industry guidance on voluntary sustainability reporting, 3rd Edition, 2015 by IPIECA, API, IOGP, since 2010 revision, guidance across social responsibility aspect has been increased because of international progress in frameworks 
and standards development. This fact also has tested in our research in the meantime which crude oil price declined.

Five social and economic issues are evaluated in this part like, community and society, local content, human rights, business ethics and transparency, and labor practices. Most of indicators are based on management's qualitative explanation as they are complicated. Following analysis are about these five indicators to clarify more detail about achieved result.

Companies strategies and understanding to address local community impact and consider how to engage with beneficiaries. Achieving trust of local communities are mandatory as oil and gas projects are typically long last and they have various impacts on local communities. As we draw frequency pie chart (see figure 6) to find out which approach is utilized more than other factors regarding local community impact and engagement, eventually the factor which is engaging with affected stakeholders and responding to their governances and its concerns is chosen as it has more frequency than others like assessing and addressing local community impact or public disclosure of information on companies' activities and management impacts. It shows that using previous experiences and therefore, existence a proper database to host all required incidents and problems are necessary.

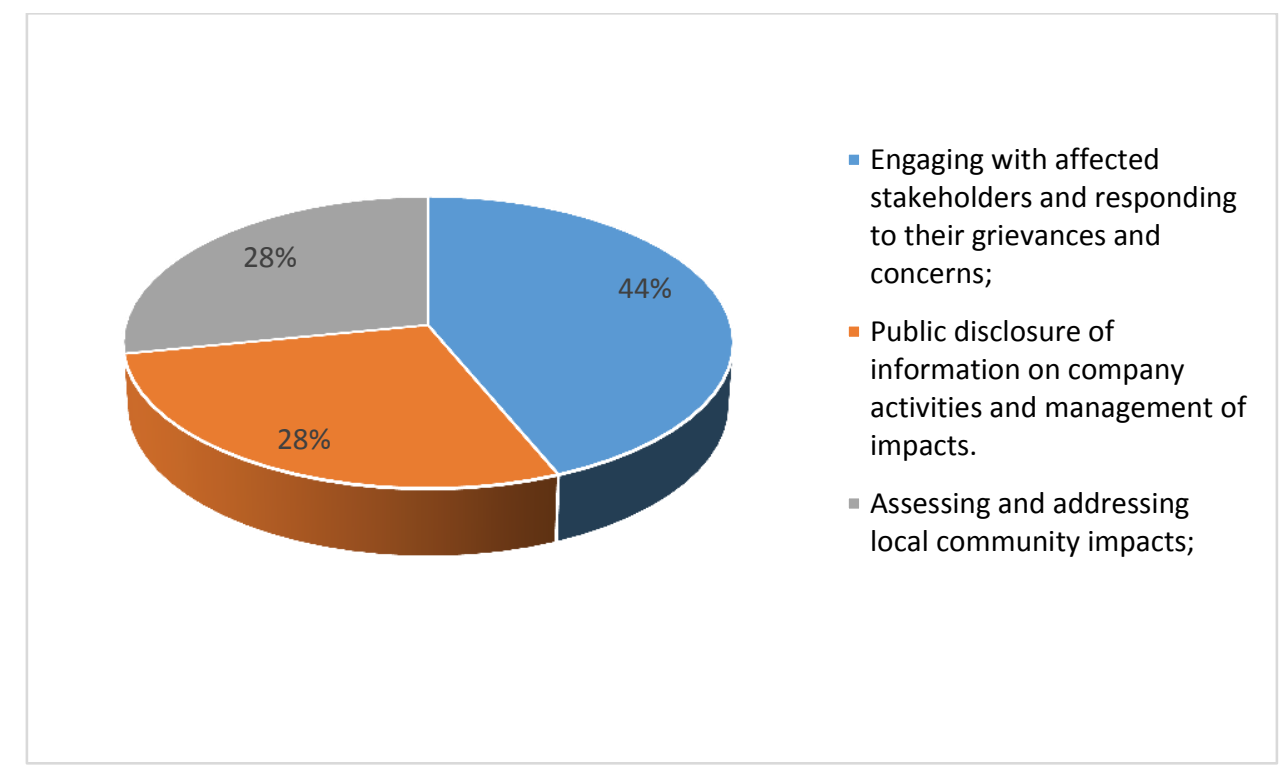

Figure 6. Local content impacts and engagement approach frequencies

Source: Authors' own research.

People's expectations and concern are desired data of this indicator. Indigenous people are always direct affect with projects in their local communities. Therefore, managing relevant interaction with indigenous people which are local group and separate from professional project's work force and normally feel projects as a threat for their livelihood, is scope of this indicator. Results state that the most used approach is to collaborate on opportunities that create mutual benefits, which is the most win - win approach among probable approaches. 


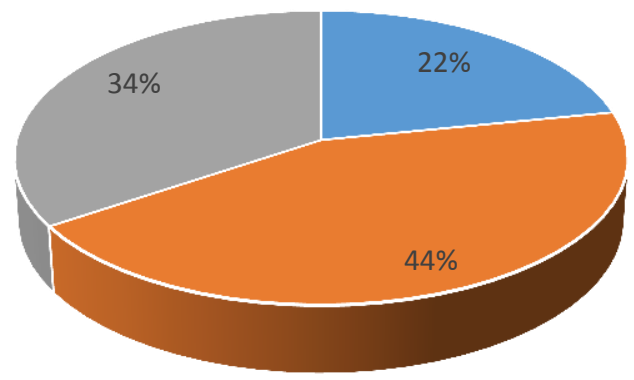

- Engage with them and address their grievances, concerns and expectations;

- Collaborate on opportunities that create mutual benefits.

- Identify and limit impacts on Indigenous Peoples;

Figure 7. Companies' approach for local indigenous people

Source: Authors' own research.

Companies' approach regarding Local issues is also one of the social and economic indicators crucial items. Frequencies state that local procurement and supplier development is strongly utilized more than local hiring practices and performances and also local content practices. Companies try to enhance using local suppliers and contactors to improve their operation and have an easier access to require products and services while reducing their costs.

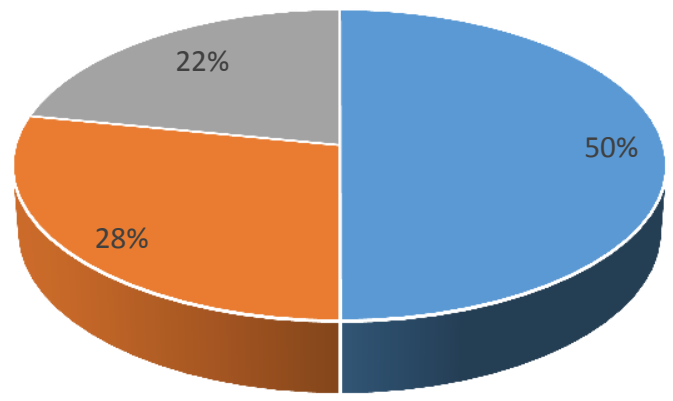

- Local procurement and supplier development

- Local hiring practices and performance

- Local content practices

Figure 8. Approach regarding local issues

Source: Authors' own research. Labor workforce is another important factor among social and economic indicator's items. Results state that workforce training and development is strongly used more than other factors which are shown in figure 9. Reveal any policies and strategies regarding workforce training and development by motivating participation at all levels. As a result, companies, could enhance their job skill, efficiency, knowledge, mobility and finally human capital. 


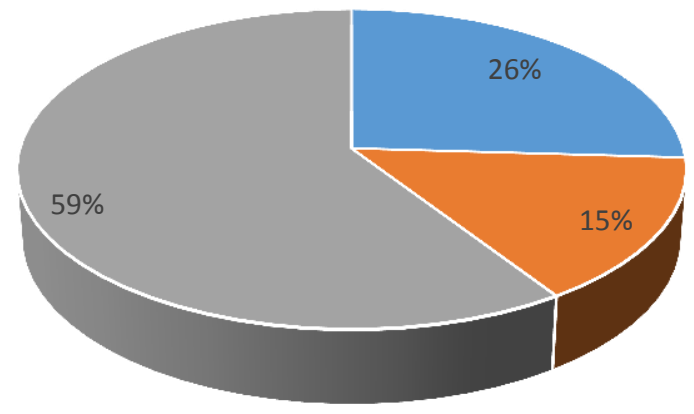

- Workforce engagement

PICBE| 166

- Non-retaliation and grievance system

- Workforce training and development

Figure 9. Approaches regarding local workforce

Source: Authors' own research.

\section{Conclusion}

The research has investigated the situation of sustainability when oil and gas industry experienced market slowdown in fourth quarter of 2014 and analyzed data from various oil and gas companies' experts by a designated questionnaire. Evaluation Sustainability issues and indicators which were asked and collected responses state that the most considered issue is social and economic. It supports our first hypothesis which was mentioned earlier, it states that when oil price fell sharply in 2014, companies concentrate more on social and economic issue of sustainability. Furthermore, second hypothesis is rejected, because the Environmental aspect of sustainability does not support by test results, so environmental aspect is not more crucial than other aspects of sustainability, in oil and gas upstream sector after oil price declination.

By oil price declination, IOCs based on their economic situation and social responsibilities, concentrate on economic and social aspects of sustainability which has derived from questionnaire responses. Therefore, environment and health and safety were not companies' priority in low oil and gas market.

To support above results, indicators were evaluated and find out following outcomes. Engaging with affected stakeholders and responding to their governances and concerns, and collaborate on opportunities that create mutual benefits are IOCs approach regarding local community impact and engagement indicator, and local indigenous people indicator. In addition, local procurement and supplier development, and workforce training and development are factors which are approached in local issues and labor workforce.

The result also illustrated that activity field of respondents and selected sustainability issues are dependent and it state that each oil and gas activity field, based on which operations they involve, concentrate on different sustainability issue. 


\section{References}

Adams W. (2006). The Future of Sustainability: Re-thinking Environment and Development in the Twenty-first Century of Conservation and Development.

Arscot (2004). Sustainable development in the oil and gas Industry, Journal of Energy Resources Technology, 126, (1), 1-5.

Ahmad W., Rezaei J., de Brito M., Tavasszy L. (2016). The influence of external factors on supply chain sustainability goals of the oil and gas industry, Resources Policy, 49 (3), 302-314.

Greener S. (2008), Business Research Methods, Ventus Publishing ApS.

Bauler, T. (2012). An analytical framework to discuss the usability of (environmental) indicators for policy. Ecological Indicators, 17, 38-45.

Baumgartner, R. (2014). Managing corporate sustainability and CSR: a conceptual framework combining values, strategies and instruments contributing to sustainable development, Corporate Social Responsibility and Environmental Management, 21, No. 5, 258-271.

Berman H. (2017). Chi-Square Test for Independence, available at: http://www.StatTrek.com.

Brundtland Report (1987). Our Common Future, Report of the World Commission on Environment and Development.

Bruin, J. (2006). Newtest command to compute new test, UCLA: Statistical Consulting Group, http://www.ats.ucla.edu/stat/stata/ado/analysis/.

Burns, R. P., \& Burns, R. (2008). Business research methods and statistics using SPSS. Sage.

Dima, A.M., Hadad, S., \& Cantaragiu, R. (2016). A conceptual analysis of business-university knowledge transfers in the energy field. ENERGY, CLIMATE CHANGE AND SUSTAINABILITY, 201-207.

EIA (2015). The U.S. Energy Information Administration, http://www.eia.gov.

FAO (2012). AQUASTAT, http://www.fao.org.

Heink, U., Marquard, E., Heubach, K., Jax, K., Kugel, C., Neßhover, C., Vandewalle,M. (2015). Conceptualizing credibility, relevance and legitimacy for evaluating the effectiveness of science-policy interfaces: challenges and opportunities. Science and Public Policy $42(5), 676-689$.

IPIECA (2016). Oil and gas industry guidance on voluntary sustainability reporting, 3rd Edition, http://www.ipieca.org.

Plackett R. (1983). Karl Pearson and the Chi-Squared Test, International Statistical Review, 51(1), 59-72.

Pupphachai U, Zuidema C. (2016). Sustainability indicators: A tool to generate learning and adaptationin sustainable urban development, Ecological Indicators 72, 784-793

Schneider J., Ghettas, S., Merdaci, N., Brown, M., Martyniuk, J., Alshehri, W., Trojan, A. (2013). Towards Sustainability in the Oil and Gas Sector: Benchmarking of Environmental, Health, and Safety Efforts, Journal of Environmental Sustainability, 3(3), Article 6.

Silvestre B., Gimenes F., Silva Neto R. (2016). A sustainability paradox? Sustainable operations in the offshore oil and gas industry: The case of Petrobras, Journal of Cleaner Production 142, 360-370.

Tordo, S. (2011). National oil companies and value creation. World Bank Publications. 